\title{
An empirical analysis of African trade blocs effects on the global economy: new evidence from the gravity model
}

\author{
David Oluseun Olayungbo ${ }^{1 *} \mathbb{D}$ and Badar Alam lqbal ${ }^{2}$
}

\begin{abstract}
This study employs the gravity model to estimate the extent of the contribution of six African trade blocs to the global economy using the gravity model spanning from 1980 to 2018. The gravity equation that models the export contributions of the six selected African RECs to the global export is estimated. The estimated gravity model reveals that the long run estimations show that the coefficient estimate for SACU and ECCAS are insignificant in the long run while SACU, EAC and ECCAS as RECs, have insignificant contribution to export in the short run. Our findings, after establishing cointegration, on the other hand show that COMESA has the highest contribution to the global exports, followed by EAC, ECOWAS and SADC with ECCAS and SACU the lowest contributors. The highest contribution of COMESA followed by EAC may be due to the growing economy of member countries like Kenya and Rwanda, while that of COMESA and SADC may be as a result of the large economy of Nigeria and South Africa respectively. This study concludes that African countries are emerging with great export potentials, therefore, governments and private sectors should create the necessary incentives and export policies for the realization of these potentials to maximise the global value chain.
\end{abstract}

Keywords: African trade blocs, COMESA, EAC, ECCAS, SACU, SADC, ECOWAS, Tariff, Gravity model

\section{Introduction}

World Bank has divided the whole world into Global North and Global South when focusing on development issues. Global North consists of developed countries, while Global South consists of low- and middle-income countries located in Asia, Africa, Latin America and the Caribbean. According to World Bank classification, most of the countries from Africa comes under the category of Global South. In the international policies, global development has become one of most important objectives, whether it is World Economic Forum (WEF), United Nation Conference on Trade and Development (UNCTAD) forum discussions, or World Bank reports. The belief is that global development is not possible along

\footnotetext{
*Correspondence: doolayungbo@oauife.edu.ng

1 Department of Economics, Obafemi Awolowo University, Ile-Ife, Nigeria Full list of author information is available at the end of the article
}

with regional imbalances in the international arena. The WEF Meeting of 2018 discussed the perils of emerging economies in terms of declining economic growth amid a global economic slowdown. The relevance of Global South has increased in recent years with the global economic slowdown. The issue around the Global South is that global development without the African development is not complete. Africa has long been a hub of natural resources and hence a contributor in the international trade. However, it remained a less developed region and failed to contribute meaningfully well in the international trading system.

Many reasons have been adduced to the low contribution of African countries to the global economy. In 2015, 27 countries out of the 28 poorest countries of the world were from sub-Saharan Africa and by 2020, in terms of population, 37.5 million out of the almost 1.4 billion of the African population live in extreme poverty [26]. In 
addition, 16 countries out of 55 African countries are landlocked countries which pose great hindrance to trade development in such countries. Therefore, the heterogeneous nature of African countries such as attribute of failed states, presence of landlocked countries, resourcerich countries and resource-poor countries are the possible reasons for slow-growth in the region [14]. However, with the formation of World Trade Organization (WTO) in 1995, and in the later years with African countries becoming member of the trading body, African countries have been integrated into the international trading systems as well as participated in the Redressal Mechanism of WTO. The changes in the recent past can further be gauged by formation of regional trading blocs in the African region. Trading blocs are comprehensive agreements binding countries and institutions for promotion of interregional and intraregional trade.

Despite the trade challenges of African countries, the economic might of Africa cannot be undermined. According to 2016 statistics of international monetary fund (IMF), the GDP per capita of Africa was USD 3260 with a GDP growth rate of $5.8 \%$. Being a less developed region, informal employment accounts for $70 \%$. According to IMF World Economic Outlook [12], three African countries are in the top 50 countries ranked as per GDP; Nigeria (28), South Africa (37) and Egypt (42). As per UNCTAD statistics of 2018, Nigeria has GDP of \$US422 billion, merchandise exports of \$US62 billion merchandise imports of \$US4 billion. South Africa has GDP of \$US368 billion, merchandise exports of \$US94 billion and merchandise imports of \$US114 billion. Egypt has GDP of \$US250 billion, merchandise exports of \$US28 billion and merchandise imports of $\$$ US72 billion. These figures are just the tip of iceberg indicating the economic potential of African countries and their emerging relevance in global economy.

Regional trade has been attributed to the promotion of export, economic growth and prosperity in the European Union (EU) $[2,5,23]$. As regards the recent associations, Africa has six trade blocs facilitating trade across different regions. Table 1 presents the details of the trade blocs operating in Africa (see "Appendix"). The present study is to examine the contribution of each trade bloc in Africa to the global economy. The study purposely focusses on export part of trade to gauge the contribution of each selected African RECs (regional economic communities) to the world export. Previous studies on African trade blocs such as Musila [15], Rojid [21], Ogbor and Eromafuru [16], Admassu [2] and Inanchi and Mahamat [11] among others have concerned themselves with trade creation and trade diversion among and outside the African trading blocs. This present paper deviates from the existing studies by examining the contributions of each African trade blocs to the global export using large number of trading partners. This study is important firstly due to the benefit of global export of African blocs in terms of income redistribution, employment generation and welfare increase in member countries. Secondly, there could be technology, cross-border trade and idea transfer. Lastly, increase in tax revenue may result from

Table 1 Regional economic communities of Trade Blocs in Africa. Source: Prepared by the authors from various sources. SADCSouthern African Development Community, COMESA-Common Market for Eastern and Southern Africa, EAC-East African Community, SACU-Southern African Customs Union (SACU), ECOWAS-Economic Community of West African States and ECCAS-EConomic Community of Central African states

\begin{tabular}{|c|c|c|c|c|}
\hline S.No & Trading Blocs & Description & Objectives & Initiation \\
\hline 1 & SADC & $\begin{array}{l}\text { An intergovernmental organization } \\
\text { headquartered in Gaborone Botswana. } \\
\text { It has } 15 \text { member countries }\end{array}$ & $\begin{array}{l}\text { Socio-economic cooperation integra- } \\
\text { tion in global economy, political and } \\
\text { security cooperation among member } \\
\text { countries }\end{array}$ & Mid 1960's and expansion in 1970s \\
\hline \multirow[t]{4}{*}{2} & COMESA & Initially known as Preferential & Formation of a Free Trade & PTA in 1981 \\
\hline & & Trade Area for Eastern and & Area & COMESA in 1994 \\
\hline & & Southern African states (PTA) & & \\
\hline & & It has 19 member countries & & \\
\hline 3 & EAC & $\begin{array}{l}\text { Regional organisation. It has } 6 \text { member } \\
\text { countries }\end{array}$ & Economic, Social and Political Integration & $\begin{array}{l}\text { Founded in 1919, collapsed in } 1977, \\
\text { revived in } 2000\end{array}$ \\
\hline 4 & SACU & $\begin{array}{l}\text { Its ally is Common Monetary Area (CMA). } \\
\text { It is } 5 \text { member countries }\end{array}$ & Custom Union for hassle Free Trade & It was established in 1910 \\
\hline 5 & ECOWAS & There are 15 member countries & Regional, Political and Economic Union & $\begin{array}{l}\text { Created by the Treaty of Lagos in Nigeria } \\
\text { on May 28th, } 1975\end{array}$ \\
\hline 6 & ECCAS & $\begin{array}{l}\text { Initially known as Custom and Economic } \\
\text { Union of Central Africa (UDEAC). } \\
\text { ECCAS has } 11 \text { member countries }\end{array}$ & Regional Economic cooperation & Formed in 1983 \\
\hline
\end{tabular}


tariff imposition and elimination of trade restriction that can result in inclusive growth. Therefore, the outcome of this study documents and provides the contribution of the different African trading blocs for the take-off of the proposed regional trade arrangement called African Continental Free Trade Agreement (AfCFTA) by African Union (AU). It will also show the extent of export the selected African trade bloc given the recent major shift of African trade to China and Asia. The major contribution of this study is that it incorporates larger African trading partners into the estimated gravity model. Specifically, we made use of 96 African trading partners in the gravity model to account for the effect of global interactions on African blocs to the global market in the estimation. Our results find COMESA to be the highest contributor to the global export both in the short and long run, followed by EAC, ECOWAS and SADC. The fast growth rate experiencing in the COMESA member countries such as Rwanda and Kenya may be responsible for the greatest contribution of COMESA followed by EAC to the global export. Also, the membership of Nigeria in ECOWAS and South Africa in SADC, which are the two largest economies in Africa, is likely reason for the high contribution of ECOWAS and SADC to the world export. The regional differences should be harnessed as comparative advantage. This study recommends that African trade blocs should maximise the process of the global value chain (GVC) to attain its economic potential in the global market. This finding supports the previous literature on African RECs that COMESA has the highest member export to the global market. Such past studies are Musila [15], Rojid [21], Admassu [2] and Inanchi and Mahamat [11]. The rest of the paper is organised as follows. After presenting the literature review and the overview of regional integration in Africa in "Review of literature" section, "Data description and descriptive analysis" section gives the variable measurement along with the descriptive analysis and the unit root test. In "Methods" section, we have the estimation method employed, while "Result and discussion" section provides the empirical analysis. Finally, "Conclusions" section concludes with policy recommendations.

\section{Review of the literature}

This section focuses and reviews appropriate and relevant studies on regional trade blocs in Africa.

\section{Empirical literature}

First and foremost, Musila [15] adopts the gravity model to examine the degree of trade creation and trade diversion in COMESA, ECCAS and ECOWAS with yearly data from the period of 1991 to 1998 . The gravity model shows a varied extent of trade creation and diversion among the
African trade blocs. ECOWAS is found to experience higher trade creation and next is COMESA. In the study, GNP, population, language and distance are the significant factors of trading activities among the Africa trading blocs. In another study, Rojid [21] first examines the trade potential within the trade blocs of COMESA using gravity model and finds COMESA to be trade creating within the COMESA blocs. The high trading potential comes through the trading abilities of Angola and Uganda. The second part of the paper by Rojid [21] uses panel data set to investigate export contribution of 147 countries between the year 1980 to 2011. The tobit model used shows that GNP, population and distance are the major determinants of trading activities. The financial integration of trading blocs has been inquired upon. This means the inquiry that how much (Degree) financially they are integrated. Applying dynamic conditional correlation generalised autoregressive conditional heteroscedasticity (DCC-GARCH) model to test the financial integration between three trading blocs of Africa, namely Common Market of Eastern and Southern Africa (COMESA), the East African Community (EAC) and the Southern African Development Community (SADC). The results of the empirical analysis show that not all countries within each of the three trading blocs are integrated to their regional factors. Moreover, the finding of the paper shows a 'decoupling' between some of the trading blocs [7]. In another study, Ngepah and Udeagha (2018) investigate regional trade agreement in Africa using panel data set from 1995 to 2014 . The estimated gravity model shows that small but significant trade benefit happens among economic and monetary community of central Africa (EMCCA), SADC, SACU and West African Economic and Monetary Union (WAMU), while trade benefit falls in EAC. Applying gravity model to study the Uganda's Intra East African Community Customs and other trading blocs was studied. The outcome of the study suggests that Uganda's trade flows have adjusted with EAC due to integration. It has been found that exports are now integrated into the EAC and COMESA regions [24]. Sub-Saharan African region is gradually integrating into Global Value Chains but there is evidence that the gap between sub-Saharan African and Global North is widening. With the help of regression, the relation between global value chain and regional trade aspects, it is concluded that GVC participation is unfavourable for many regional countries, particularly due to non-upgraded production units [10]. Applying data set of 148 countries for the period 1970 to 2010, there is strong evidence that African regional economic communities increase their members exports and imports. African exports have increased by $175 \%$ due to trade integration and imports by $200 \%$ [2]. The trade-creating effect of the main African 
Regional Trade Agreements is investigated using gravity model with Poisson pseudo-maximum-likelihood estimator. There is found heterogeneity in the emerging regional trade agreements. The meta-analysis shows a positive impact of trade bloc agreements on growth and development for Africa. The general positive effect is between the range 27 to $32 \%$ [3]. Furthermore, Inanchi and Mahamat [11] investigate trade creation and trade diversion in ECCAS from the year 2007 to 2016. The study also employs gravity model and the result reveals that corruption, GDP, population, distance and political stability are important factors for trade activities. In conclusion, CEMAC, COMESA and EAC are significant contributors to trade creation in the region. In more recent papers, Jambo [13] analyses the benefits of regional integration from COMESA for Zambia from the period of 1975 to 2017 using autoregressive distributed lag (ARDL) model. The results after, conducting unit root tests and cointegration, finds Zambia to benefit from joining COMESA. The study recommends removal of non-tariff barriers among member countries to increase trade benefits among members. Finally, the review of the study suggests that many studies have been carried out on African trade blocs but no known study to the best of our knowledge has been done to account for global trading activities in the analysis of African trade blocs, which this study fills.

\section{Theories of trade}

There are many theories of international trade; some are absolute cost advantage, comparative cost advantage and the gravity theory. The absolute cost advantage was propounded by Adam [1] that a country has an absolute advantage if it can export a commodity absolutely better than another country given the same resources. The limitation of the absolute cost advantage later gave way to the comparative cost advantage where a country can efficiently export a commodity in which it has a lower opportunity cost over other country as propounded by Ricardo [22]. The Ricardian theory gave way to specialisation and wealth in international trade. One of the limitations of the comparative cost advantage is how to measure efficiency among countries with more than two commodities. The next theory is the gravity theory pioneered by Ravenstein [20] in the UK in the nineteenth century to explain migration pattern. The model was later adapted to explain trade flows between countries by Tinbergen [25]. The gravity model states that the value of export increases between trading countries with their GDPs and decreases with their geographical distances [18]. The gravity model has its theoretical foundation from the Ricardian theory of trade where countries engage in trading activities because of the comparative advantage they have over one another.

\section{An overview of regional integration in Africa}

The fragmentation and smallness of each of the African country in respect to the global economy have necessitated the coming together of these countries to form regional trade blocs in order to be well positioned to benefit from the global trade. The SACU and EAC, for instance, were the pioneer regional blocs formed in the year 1910 and 1919 respectively. Between 1957 to 1960, due to formation of European Economic Community (EEC) and Free Trade Area (FTA), regionalism started to become popular both in the developing and developed countries. And by the late 1980s and early 1990s when powerful trade blocs began to emerge in the global scene, SADC, ECOWAS, COMESA (formerly PTA), and ECCAS were formed in 1970, 1975, 1981 and 1983 respectively. It has been established that these African blocs are exporters of primary products in their raw form [17]. The major reason has been the low level of industrialization in African countries which has hindered them to take full advantage of the global value chains (GVCs) in the international trading system. In other words, the primary commodities from African countries serve as the raw materials for the developed industrialized economies. Examples of the commodity exports of African blocs to the outside world are crude oil, cotton, fish, copper, cocoa, tea, diamond, tobacco, iron ore coffee, gold, tin ore among others World Development Indicator [26]. The destination of larger percentage of African countries' exports are to Europe, Asia, China, United States (US) and advanced countries [2]. The percentage proportion of the African regional economic communities' (RECs) exports to the world exports in 2018 was $0.6 \%$ for SADC, SACU and ECOWAS, $0.001 \%$ for EAC, $0.5 \%$ for COMESA, and $0.4 \%$ for ECCAS. The RECs pattern of exports to the world is confirmed in Table 2, where both EAC and ECCAS have the lowest volume of export to the

Table 2 Trade potential of African economic communities in 2018. Source: IMF, Direction of Trade and Statistics (2020). GDP and trade figures are expressed in billion \$US

\begin{tabular}{lccclr}
\hline REC & GDP & $\begin{array}{l}\text { Number of } \\
\text { member states }\end{array}$ & Exports & Imports & Trade \\
\hline SADC & 694.2 & 16 & 113.8 & 126 & 239.8 \\
COMESA & 666.9 & 19 & 105.3 & 174.4 & 279.7 \\
EAC & 226.8 & 6 & 15.3 & 37.1 & 52.4 \\
SACU & 408.9 & 5 & 111.6 & 117.7 & 229.3 \\
ECOWAS & 609.6 & 15 & 112.3 & 174.4 & 286.7 \\
ECCAS & 223.7 & 11 & 85.5 & 47.6 & 133.1 \\
\hline
\end{tabular}


world with \$US15.3 billion and \$US85.5 billion respectively. The volume of the RECs exports also seems to correspond with their level of GDP. SADC with the highest GDP value of \$US694.2 billion also had the highest volume of export worth of \$US113.8 billion in 2018 from Table 2. This goes for COMESA, ECOWAS and SACU. The total GDP of all the RECs in 2018 amounts to \$US2.8 trillion which is relatively small compared to the GDP of US with \$US20.5 trillion, European Union with \$US18.8 trillion and China with \$US13.4 trillion [26]. It could also be observed that all of the RECs experienced trade deficit in 2018 from Table 2 except ECCAS with trade surplus worth of \$US37.9 billion. The aggregate export contribution of all the RECs to world export in 2018 was $2.7 \%$ which is relatively small compared to their counterparts in European and Asia.

\section{Data description and descriptive analysis Data description}

This section provides the distribution of the data employed and the measurement of the variables used in the empirical analysis for the period of 1980 to 2018 . The choice of the starting date is due to data availability and 1980s also marks the beginning of the emergency of many regional trade blocs in Africa. All the data used were sourced from both International Monetary Fund [12] and the WDI [26]. The selected 96 trading partners of the African trading blocs capture the trading global economy (see "Appendix" in Table 8). The selected 96 African trading partners are the major trading countries of the selected African trade bloc. Some of these countries are either member of EU or Asia. These countries are incorporated into our analysis to capture global effect of trade. Basically, the exports of African countries are mostly to the UK, USA, China, Asia and the EU [2] and these African trading countries are well captured in this paper as presented in "Appendix" in Table 8. The RECs employed in this study are COMESA, EAC, ECCAS, ECOWAS, SACU and SADC (see "Appendix" in Table 7 and 9). The selected six RECs are chosen based on the closeness of their formation to the starting date of 1980 to ensure data availability. The variables employed are value of exports of the six selected RECs in Africa measured in US dollar, the export tariff paid by the African RECs to their trading partners which is in percentage, the RECs GDP, the GDP and the Africa's exports to the trading partners during the period of study.

\section{Descriptive analysis}

All the values of exports of the selected six RECs with their GDPs, the Africa's exports, the RECs export tariff and the trading partners' GDPs are presented in descriptive terms in Table 3. From the table, ECOWAS happens to export highest value among the selected RECS over the study period with a maximum value of \$US155.4 billion, followed by SADC with $\$$ US128.9 billion and EAC with the lowest value of \$US18.5 billion. The highest GDP of the six selected RECs amounts to \$US1.49 trillion while the trading partners' GDP is \$US78.2 trillion over the period of study. This implies that the RECs GDP represents $1.92 \%$ of the trading partners' GDP. The maximum value of the Africa's export (AFRIEXP) is around \$US19.3 trillion with a minimum value of \$US1.72 billion over the study period. The highest export tariff paid by the RECs countries is $295 \%$ and the minimum rate of $1.29 \%$ over the study period. Lastly, unobservable variables that can affect Africa's exports such as different languages, landlocked countries and multi-membership of trade blocs were used in the estimation but they are not presented in Table 3 due to space constraint.

\section{Tests}

The next thing is to test for the order of integration of the variables employed. The unit root test is important to

Table 3 Descriptive analysis

\begin{tabular}{lllllllll}
\hline Statistics & Mean & Median & Maximum & Minimum & Std-dev & Jacque-Bera & Prob & Observation \\
\hline COMESA & $44,910.21$ & $25,166.91$ & $112,283.5$ & $14,982.43$ & $33,006.19$ & 6.02 & 0.04 & 39 \\
EAC & 6103.04 & 3219.18 & $18,542.2$ & 1668.04 & 5304.6 & 7.3 & 0.02 & 39 \\
ECCAS & $37,547.2$ & $139,444.4$ & $117,218.4$ & 5802.1 & $36,588.1$ & 6.11 & 0.04 & 39 \\
ECOWAS & $52,396.11$ & $26,449.36$ & $155,415.1$ & 6853.72 & $45,778.63$ & 6.8 & 0.03 & 39 \\
REC GDP & $6.43 \mathrm{E}+11$ & $4.00 \mathrm{E}+11$ & $1.49 \mathrm{E}+12$ & $1.80 \mathrm{E}+11$ & $4.75 \mathrm{E}+11$ & $5.83 \mathrm{E}+00$ & $5.00 \mathrm{E}-02$ & 39 \\
Trading partner GDP & $3.75 \mathrm{E}+13$ & $3.06 \mathrm{E}+13$ & $7.82 \mathrm{E}+13$ & $9.95 \mathrm{E}+12$ & $2.21 \mathrm{E}+13$ & $3.56 \mathrm{E}+00$ & $1.60 \mathrm{E}-01$ & 39 \\
SACU & $73,693.64$ & $73,448.03$ & $123,029.1$ & $24,421.47$ & $33,480.23$ & -0.11 & 0.39 & 39 \\
SADC & $42,307.43$ & $27,946.8$ & $128,950.1$ & 1943.96 & $44,890.7$ & 4.89 & 0.09 & 39 \\
Tariff & 141.04 & 143.42 & 295.11 & 1.29 & 79.8 & 0.38 & 0.83 & 39 \\
AFRIEXP & $8,308,073$ & $5,663,375$ & $19,321,110$ & $1,727,834$ & $6,168,571$ & 4.66 & 0.09 & 39 \\
\hline
\end{tabular}


know the estimation method to be adopted to avoid unbiased results. The augmented Dickey-Fuller [8] and the Phillips-Perron [19] are employed to ascertain the correct order of integration of the variables. Table 4 shows that all the variables are I(I) which necessitates the cointegration test. The time-invariant variables such as language, landlocked and the multi-member variables were not included in the unit root results in Table 4 because the variables are ones and zero that do not change over time only across the countries.

\section{Methods}

This study adopts the gravity model of international trade theory. The gravity model is a model that helps to explain bilateral trade between two trading countries. Although there are various models that can be employed to examine the contribution or effect of trade bloc on global export, such as computable general equilibrium (CGE) model and others, the superiority and relevance of gravity model in this study emanate from its ability to explain comparative advantage between two trading countries. The gravity model fits our analysis so well that it explains why African countries export raw materials to the developed countries and import manufactured good from them. Previous studies that have used the gravity model for empirical analysis are Anderson and van Wincoop [4], Bergstrand and Egger [6], Olayungbo et al. [18], Adamassu [2], among others.

The gravity model can be stated as:

$$
\text { Export }_{i j t}=A Y_{i t}^{\alpha} D_{i j t}^{\beta}
$$

Equation (1) implies that export of goods supplied from origin $i$ to destination $j$ at time $t$ depends on the size of the exporting country $i$ at time $t$ and the distance between the country of origin $i$ (exporting country) and country of destination $j$ (importing country) at time $t$. The $A$ is the constant term, $\alpha$ measures the proportional change in the size of the exporting country to the value of export, while $\beta$ accounts for the change in the distance between trading to the value of export. We expect $\alpha>0$ and $\beta<0$, which implies that exports increase with the size of the country and decrease with distance. Linearising Eq. (1) leads to:

$$
\log \left(\exp \text { ort }_{i j t}\right)=a+\alpha y_{i t}+\beta d_{i j t}
$$

Equation (2) can be written in econometric form by introducing the error term as:

$$
\log \left(\exp \operatorname{ort}_{i j t}\right)=a+\alpha y_{i t}+\beta d_{i j t}+\varepsilon_{t}
$$

Furthermore, other factors that determine the exports are incorporated and Eq. (3) becomes:

$$
\begin{aligned}
& \log \left(\exp \operatorname{ort}_{i j t}\right)=a+\alpha \log \left(G D P_{i t}\right)+\beta \log \left(G D P_{j t}\right) \\
& +\beta_{1} \log \left(\text { tariffijt }_{i j}\right) \\
& +\beta_{2} \log \left(\text { COMESA }_{i j t}\right)+\beta_{3} \log \left(E A C_{i j t}\right) \\
& +\beta_{4} \log \left(E C C A S_{i j t}\right) \\
& +\beta_{5} \log \left(E_{C O W A S_{i j t}}\right)+\beta_{6} \log \left(S A C U_{i j t}\right) \\
& +\beta_{7} \log \left(S A D C_{i j t}\right) \beta_{8} \text { language }_{i j} \\
& +\beta_{9} \text { landlock }_{i j}+\beta_{10} \text { multi_member }_{i j}+\varepsilon_{t}
\end{aligned}
$$

where $\log \left(\exp\right.$ ort $\left._{i j t}\right)$ is sum of the log of the exports of the

\begin{tabular}{|c|c|c|c|c|c|c|c|}
\hline \multicolumn{4}{|c|}{ Augmented Dickey Fuller Test (ADF) } & \multicolumn{4}{|c|}{ Phillips-Perron Test (PP) } \\
\hline Variables & Levels & First Diff & Status & Variables & Levels & First Diff & Status \\
\hline COMESA & -2.6035 & -5.3486 & $I(1)$ & COMESA & -2.6117 & -5.3403 & $\mathrm{I}(1)$ \\
\hline EAC & -2.3683 & -6.9215 & $\mid(1)$ & EAC & -0.5156 & -6.0027 & $\mathrm{I}(1)$ \\
\hline ECCAS & -2.0996 & -7.3932 & $\mid(1)$ & ECCAS & -2.0871 & -7.528 & $\mathrm{I}(1)$ \\
\hline ECOWAS & -2.9309 & -9.3775 & $\mid(1)$ & ECOWAS & -1.6228 & -7.0793 & $\mathrm{I}(1)$ \\
\hline REC GDP & -2.0110 & -4.2583 & $\mid(1)$ & REC GDP & -1.8386 & -4.3335 & $\mathrm{I}(1)$ \\
\hline Trading partner GDP & -1.9873 & -4.2686 & $\mid(1)$ & Trading partner GDP & -1.5043 & -4.212 & $\mathrm{I}(1)$ \\
\hline SACU & -1.9669 & -5.9818 & $\mid(1)$ & SACU & -2.0178 & -5.9817 & $I(1)$ \\
\hline SADC & -1.9922 & -6.7172 & $\mid(1)$ & SADC & -1.8453 & $-49,251$ & $\mathrm{I}(1)$ \\
\hline Tariff & 1.0000 & -5.5987 & $\mid(1)$ & Tariff & -2.9456 & -6.0894 & $\mid(1)$ \\
\hline AFRIEXP & -2.1081 & -5.3283 & $\mid(1)$ & AFRIEXP & -2.3335 & -5.3292 & $\mid(1)$ \\
\hline
\end{tabular}
African countries to the selected trading partners during the study period sourced from IMF [12]. $\log \left(G D P_{i t}\right)$ and $\log \left(G D P_{j t}\right)$ are the $\log$ of GDP of country $i$ and country $j$ over the study period. The country $i$ in this case are the six selected African trading blocs while country $j$ are their trading partners. In this study, we use ordinary least square (OLS) estimation after grouping the selected African countries into their member trade blocs. This

Table 4 Results of the unit root tests

Critical values for ADF are $-4.2268,-3.5366$, and -3.2003 for $1 \%, 5 \%$ and $10 \%$

Critical values for PP are $-4.2191,-3.5330$ and -3.1983 for $1 \%, 5 \%$ and $10 \%$, 
grouping method of regression analysis is better than the other estimation techniques such as fixed effect regression with time invariant, pooled regression analysis and country pair fixed effects. This method has the advantage and possibility of countries' grouping into different regional blocs and still account for the unobservable such as language, multiple membership and so on. What makes our modelling and estimation novel is that we are able to model and account for the trading effects of the selected 96 African trading partners. This is because no nation in the world trades in autarky, i.e. no nation exists in isolation. Every country has to trade with the outside world. Such global effects were not taken into consideration in previous studies. Adamassu [2] adopted the same countries' grouping analysis in his study but also failed to account for global trading effects. This study therefore takes into consideration the trading partners of the African countries. And the trading partners to the selected African countries used in this study are 96 non-African countries (see "Appendix" in Table 8), which represent close to $90 \%$ of the world trading countries [12]. The nonAfrican 96 trading partners are listed in "Appendix". Also, $\log \left(\right.$ tariff $\left._{i j t}\right)$ is the sum of the value of export taxes paid by the African trading blocs to their trading partners over the study period sourced from WDI [26]. The tariff rate in percentage is a proxy for the distance in the gravity model. Past study such as Olayungbo et al. [18] used trade tariff as a proxy for distance. The $\log \left(C O M E S A_{i j t}\right)$, $\log \left(E A C_{i j t}\right), \log \left(E C C A S_{i j t}\right), \log \left(E C O W A S_{i j t}\right), \log \left(S A C U_{i j t}\right)$ and $\log \left(S A D C_{i j t}\right)$ are the sum of the value of exports of the RECs to the selected trading countries over the study period. Lastly, language $_{i j}$ is a time-invariant variable of one if the REC country uses English as its official language and zero otherwise, landlock $k_{i j}$ is also a dummy variable that assumes one if the REC country is a landlocked country and zero otherwise and multi_member ${ }_{i j}$ is a dummy variable that assumes a value of one if the REC country is a member of more than one trading blocs while $\varepsilon_{t}$ is the error term. The Engle and Granger [9] single equation cointegration test is adopted in this study given the I(1) order of integration of the variables. The Engle and Granger is a two-step procedure in which a linear combination of dependent and independent variables is first estimated and a unit root test is thereafter conducted on the residual to test for its stationarity (see "Appendix" in Table 10). If the test statistic is greater than the critical values, then the residual is stationary, then it is said that cointegration exists between the dependent and the independent variables. To account for the adjustment from disequilibrium to equilibrium, then Eq. (4) can be written in an error correction model $(\mathrm{ecm})$ and short-run form as:

$$
\begin{aligned}
\log \left(\Delta \exp \text { ort }_{i j t}\right)= & a+\alpha \log \left(\Delta G D P_{i t}\right)+\beta \log \left(\Delta G D P_{j t}\right) \\
& +\beta_{1} \log \left(\Delta \text { tariffijt }_{i j}\right)+\beta_{2} \log \left(\Delta \text { COMESA }_{i j t}\right) \\
& +\beta_{3} \log \left(\Delta E A C_{i j t}\right) \\
& +\beta_{4} \log \left(\Delta E C C A S_{i j t}\right)+\beta_{5} \log \left(\Delta E C O W A S_{i j t}\right) \\
& +\beta_{6} \log \left(\Delta \text { SACU }_{i j t}\right) \\
& +\beta_{7} \log \left(\Delta \text { SADC }_{i j t}\right)+\beta_{8} \text { language }_{i j} \\
& +\beta_{9} \text { landlock }_{i j} \\
& +\beta_{10} \text { multi_member }_{i j}+\lambda \varepsilon_{t-1}+\mu_{t}
\end{aligned}
$$

\section{Results and discussion}

This section presents both the long-run and the shortrun results of our estimation.

\section{Long-run analysis}

We first estimated the long-run equation in Eq. (4) and then presented its result in Table 5. The long result as presented in Table 5 shows that the regression model is efficient and unbiased given the R-squared value of $0.99 \%$. The $\mathrm{R}$-squared value explains $0.99 \%$ variation in the world export (dependent variable) due to variation in the explanatory variables. This means that the

\begin{tabular}{|c|c|c|c|c|}
\hline Variable & Coefficient & Std. Error & t-statistics & Prob \\
\hline$G D P_{i t}$ & -0.3253 & 0.0809 & -4.0202 & $0.00^{* * *}$ \\
\hline$G D P_{j t}$ & 1.0831 & 0.0672 & 16.1163 & $0.00^{* * *}$ \\
\hline Tariff & 0.0100 & 0.0044 & 2.2755 & $0.03^{* *}$ \\
\hline COMESA & 0.2280 & 0.0418 & 5.4497 & $0.00^{* * *}$ \\
\hline EAC & 0.0986 & 0.0367 & 2.6847 & $0.01^{* *}$ \\
\hline ECCAS & -0.0243 & 0.0455 & -0.5360 & 0.59 \\
\hline ECOWAS & 0.0805 & 0.0297 & 2.7106 & $0.01^{* *}$ \\
\hline SACU & -0.0012 & 0.0037 & -0.3217 & 0.75 \\
\hline SADC & 0.0551 & 0.0169 & 3.2543 & $0.00^{* * *}$ \\
\hline language & 0.0090 & 0.0140 & 0.8426 & 0.53 \\
\hline landlock & -0.0022 & 0.0145 & -0.1519 & 0.88 \\
\hline Multi_member & 0.0117 & 0.0182 & 0.6448 & 0.82 \\
\hline constant & -13.6345 & 1.0009 & -13.6222 & $0.00^{* * *}$ \\
\hline $\mathrm{R}$ - squared & 0.99 & $\begin{array}{l}\text { Durbin Wat- } \\
\text { son Stat }\end{array}$ & 1.86 & \\
\hline Standard error & 0.03 & & & \\
\hline $\begin{array}{l}\text { Sum of squared } \\
\text { residual }\end{array}$ & 0.03 & & & \\
\hline
\end{tabular}
explanatory variables explain much of the variation in the world exports. In addition, the Durbin-Watson value of 1.86 closer to 2 indicates absence of autocorrelation in the residual. This is also confirmed with low value of $0.03 \%$ for both the standard error and the sum of squared residual, respectively. The regression results show that

Table 5 The long run result. Dependent variable: Export ${ }_{i j t}$

*** ,and ${ }^{* *}$ indicate $1 \%$ and $5 \%$ significance level 
the coefficient of the GDP of the selected African countries represented by $i$ at time $t$ is -0.3253 meaning that there is negative effect of GDP of the RECs countries on the world export at $0.01 \%$ significance level in the long run. The implication of this result is that the GDP of the RECs is not large enough to contribute to the growth of the world exports, hence the negative effects in the long run. On the other hand, the coefficient of GDP of the 96 trading countries is positive with a value of 1.083 and significant at $0.01 \%$ significance level in the long term. We can interpret this to mean that $1 \%$ increase in the GDP would lead to $1.08 \%$ in the world export. This implies that the GDP of the 96 trading partners to the African RECs is so huge that it contributes positively to the world exports. Unexpectedly, export tariff, a proxy for distance, has a positive effect on the world export. $1 \%$ increase in export tariff between the trading partners and the African RECs increase world export by $0.01 \%$. This implies that increase in the export tariff by the trading countries does not discourage export of the African RECs. Among the six selected African RECs, we found COMESA, EAC, ECOWAS and SADC export to positively contribute to the world exports with values such as $0.2280,0.0986,0.0805$ and 0.0551 , respectively. On the other hand, ECCAS and SACU export contribute negatively with values of -0.0243 and -0.0012 , respectively. Out of the six African RECs, COMESA export contributes the highest percentage to the world export with a value of $0.23 \%$ at $0.01 \%$ significance level, followed by EAC export with $0.10 \%$ and ECOWAS export by $0.08 \%$ at $0.05 \%$ significance level. Our finding is similar with some previous studies on African RECs such as Musila [15], Rojid [21], Admassu [2] and Inanchi and Mahamat [11] which concluded that ECOWAS and COMESA have contributed largely to trade creation in their blocs. Possible reasons for the positive contributions of the exports of the COMESA, EAC, ECOWAS and SADC to the world export is that the RECs consist of Nigeria, South Africa, Kenya and Rwanda. Among the countries, Nigeria is the largest economy in Africa with a value of \$US444,916 billion followed by South Africa with a GDP value of $\$$ US371,367 [26]. According to [2], up to $77 \%$ of the ECOWAS exports is from Nigeria, while $60 \%$ of the SADC exports is from South Africa. The huge GDP of these two countries is the likely reason for the positive contribution of the 4 RECs to the world export. The positive contribution of COMESA and EAC exports can be traced to the exports of both Kenya and Rwanda. It is reported that $73 \%$ and $67 \%$ of exports in the EAC and COMESA are usually from Kenya [12] with Rwanda being the fastest growing economy in Africa. Lastly, we found unobservable variables such as membership of more than one blocs, the different languages among the
Table 6 The short run result. Dependent variable: D(export ijt)

\begin{tabular}{|c|c|c|c|c|}
\hline Variable & Coefficient & Std. Error & t-statistics & Prob \\
\hline $\mathrm{D}\left(G D P_{i t}\right)$ & -0.1413 & 0.1081 & -1.3070 & 0.20 \\
\hline $\mathrm{D}\left(G D P_{j t}\right)$ & 1.0532 & 0.1337 & 7.8743 & $0.00^{* * *}$ \\
\hline D(Tariff) & 0.0034 & 0.0043 & 0.7903 & 0.44 \\
\hline D(COMESA) & 0.1626 & 0.0519 & 3.1360 & $0.00^{* * *}$ \\
\hline $\mathrm{D}(\mathrm{EAC})$ & 0.0374 & 0.0397 & 0.9431 & 0.35 \\
\hline $\mathrm{D}(\mathrm{ECCAS})$ & 0.0433 & 0.0418 & 1.0383 & 0.31 \\
\hline D(ECOWAS) & 0.0736 & 0.0212 & 3.4726 & $0.00^{* * *}$ \\
\hline $\mathrm{D}(\mathrm{SACU})$ & -0.0010 & 0.0029 & -0.1606 & 0.87 \\
\hline$D(S A D C)$ & 0.0506 & 0.0146 & 3.4728 & $0.00^{* * *}$ \\
\hline language & -0.0102 & 0.0169 & -0.6020 & 0.56 \\
\hline landlock & 0.0068 & 0.113 & 0.6043 & 0.55 \\
\hline Multi_member & -0.0219 & 0.0172 & -1.2695 & 0.22 \\
\hline ECM & -0.8071 & 0.1838 & $-4 / 3908$ & $0.00^{* * *}$ \\
\hline constant & -0.0079 & 0.0074 & -1.0688 & 0.29 \\
\hline R-squared & 0.94 & $\begin{array}{l}\text { Durbin Wat- } \\
\text { son Stat }\end{array}$ & 1.74 & \\
\hline Standard error & 0.03 & & & \\
\hline $\begin{array}{l}\text { Sum of squared } \\
\text { residual }\end{array}$ & 0.02 & & & \\
\hline
\end{tabular}

***Indicates $1 \%$ significance level

trading blocs and landlock to have insignificant effects on the export of the African countries.

\section{Short-run analysis}

After long-run analysis, we proceed to the short-run analysis and the result reported in Table 6. From the result, the R-squared, Durbin-Watson, sum of squared residual and the standard error of the regression model perform well. The short-run result shows that the GDP of the African RECs is also negative like the long-run result. $1 \%$ change in the GDP of the RECs would lead to negative effect of a reduction in world export by $0.14 \%$, though not significant. In contrast, we found the GDP of the 96 trading partners of the African RECs to significantly promote world export by $1.05 \%$ at $1 \%$ significance level. The result is also similar with the long run. The result for the tariff in the short run is almost similar with the long run. In the short run, tariff has positive effect on the world export with a value of 0.0034 but not significant as the long run. All the shortrun result of the RECs are similar with the long run except with ECCAS with positive effect in the short run. One of the possible reasons for the variation from positive effect of ECCAS contribution to negative effect in the long run may be due to the fact that many member countries in ECCAS like Burundi, Chad, Cameroon and Central African Republic are landlocked countries. The further away of these countries from seaports could be a hindrance to their free flow of exports to the outside world. Our finding on ECCAS supports the study of Musila [15] that 
trade creation is weak in ECCAS trade bloc. On the other hand, COMESA has significant positive contribution of $0.16 \%$ export to the world export, EAC contributes 0.04\% in the short run as oppose $0.10 \%$ in the long run, ECCAS also contributes $0.04 \%$ export in the short run as against $0.02 \%$ export in the long run, ECOWAS contributes $0.07 \%$ export to the world export in the short run as against $0.08 \%$ in the long run, SACU contributes low and negative value of $-0.0001 \%$ export to the world export lower than the long-run contribution of $-0.001 \%$ and Lastly, SADC contributes almost similar positive value of $0.05 \%$ in the short run as compared to the long-run value of $0.06 \%$. In overall, we found COMESA to remain the highest contributor of export to the global export both in the short and the long run. The regional differences imply that some African blocs export more than the others and have the potential to benefit from one another. Such regional differences can enhance inter-trade relation among African countries through comparative advantage. On the global scale, the regional differences can promote trade specialisation and increase exportation of specialised products to the outside world for more income generation, attraction of foreign direct investment and poverty reduction for African region. All the unobservable such as language, landlocked and multi-member variables have insignificant impacts on the exports of the African countries in the short-run analysis as presented in Table 6 . This is similar to the long-run result. We, therefore, conclude that the different languages, landlocked countries and multi-membership of trade blocs do not have significant impact on the exports of African countries. Finally, the ECM term performs as expected with negative value $(-0.8071)$ and significant at $1 \%$ level. It would take $0.81 \%$ for the short-run deviation to return to equilibrium level, which is very high.

\section{Conclusions}

This study examines the contribution of export of the six selected African RECs to the global export of African countries from the period of 1981 to 2018 with a view to ascertain the contribution of each RECs to the global economy. After estimating a gravity model with the 96 trading partners of the African RECs, we found COMESA to be the highest contributor to the global export both in the short and long run. This is followed by EAC, ECOWAS and SADC. Member countries such as Nigeria, South Africa, Kenya and Rwanda are found to make huge impact in the export value of the African RECs. The African RECs are indeed emerging towards becoming players to be reckoned with in the global scene. We, therefore, recommend that African countries should be more involved in the global value chain in other to improve the value of their exports. This implies that African countries should improve on the exportation of their primary products such as cocoa, tuber, crude oil, cassava, yam tuber, gold and other primary products and leverage on their comparative advantages. Lack of technology, innovation and investment in research has been hindering the improvement in the value of export in Africa. This study provides the background information essential for the take-off of the recent proposed African regional trade agreement called African Continental Free Trade Agreement (AfCFTA) by African Union (AU). Government and private sectors are therefore advised to take advantage of the export potential in Africa by investing and creating incentives for export in African countries.

\section{Appendix}

See Tables 7, 8, 9, and 10.

Table 7 Members of African Regional Economic Communities. Source: Author's computation from various sources

\begin{tabular}{lllll}
\hline 1. SADC & Angola & Botswana & Comoros & Congo Dem \\
Lesotho & Madagascar & Malawi & Mauritius & Mozambique \\
Seychelles & South Africa & Tanzania & Zambia & Zimbabwe \\
2. COMESA & Burundi & Comoros & Congo Dem & Djibouti \\
Eritrea & Ethiopia & Kenya & Libya & Madagascar \\
Mauritius & Rwanda & Sudan & Swaziland & Seychelles \\
Zambia & Zimbabwe & & & \\
3. EAC & Burundi & Kenya & Rwanda & South Sudan \\
Tanzania & & & & \\
4. SACU & Botswana & Lesotho & Namibia & South Africa \\
5. ECOWAS & Benin & Burkina Faso & Cabo Verde & Cote d'ivoire \\
Ghana & Guinea & Guinea Bissau & Liberia & Mali \\
Nigeria & Senegal & Sierra Leone & Togo & Uganda \\
6. ECCAS & Angola & Burundi & Cameroun & Central of African Rep \\
Congo & Congo Dem & Equatorial Guinea & Gabon & Sambia Tome and Principle \\
\hline
\end{tabular}


Table 8 The List of 96 Selected Trading Countries with Africa. Source (IMF, 2020)

\begin{tabular}{|c|c|c|c|c|c|}
\hline Afghanistan & Austria & Armenia & Azerbaijan & Argentina & Antigua and Barbara \\
\hline Australia & Aruba & Bahamas & Bahrain & Bangladesh & Bosnia Herzegovina \\
\hline Barbados & Belarus & Belize & Bermuda & Bolivia & Brazil \\
\hline Belgium & Canada & China & Chile & Columbia & costa Rica \\
\hline Cuba & Cyprus & Czech Rep & Denmark & Dominica & Ecuador \\
\hline El Salvador & Finland & France & Germany & Greece & Georgia \\
\hline Greenland & Guatemala & Guyana & Hong Kong & Haiti & Honduras \\
\hline Ireland & Italy & Israel & India & Indonesia & Iran \\
\hline Iraq & Japan & Jamaica & Jordan & Korea Dem & Kazakhstan \\
\hline Kyrgyz Rep & Latvia & Luxembourg & Lebanon & Malta & Malaysia \\
\hline Mexico & Montenegro & Moldova & Netherlands & new Zealand & Norway \\
\hline North Korea & Nicaragua & Oman & Paraguay & Peru & Poland \\
\hline Panama & Pakistan & Qatar & Russian & Romania & Sweden \\
\hline Switzerland & Suriname & Singapore & Spain & Serbia & St Kitts and Nevis \\
\hline St Lucia & St Vincent and Greens & Tajikistan & Thailand & Turkey & Turkmenistan \\
\hline United Kingdom & United States & Uruguay & Uzbekistan & Venezuela & Yemen \\
\hline
\end{tabular}

Table 9 Variable description. Source: export, COMESA, EAC, ECCAS, ECOWAS, SACU, SADC were sourced from IMF (2020) while the GDPs and Tariff were sourced from WDI [26]

\begin{tabular}{llll}
\hline $\mathbf{s} / \mathbf{n}$ & Variable & Definition & Units \\
\hline 1 & export & Sum of the African countries exports to the 96 trading partners over the study period & Measured in US dollar \\
2 & GDP & Sum of the value of goods and services produced by the African RECs countries over the study period & Measured in US dollar \\
3 & GDP & Sum of the value of goods and services produced by the selected 96 trading partners over the period & Measured in US dollar \\
4 & Tariff & Tariff rates paid on exports by the selected African RECs over the study period & Measured in percentage \\
5 & COMESA & Sum of the value of exports by COMESA member & Measured in US dollar \\
6 & EAC & Sum of the value of exports by EAC member & Measured in US dollar \\
7 & ECCAS & Sum of the value of exports by ECCAS member & Measured in US dollar \\
8 & ECOWAS & Sum of the value of exports by ECOWAS member & Measured in US dollar \\
9 & SACU & Sum of the value of export by SACU member & Measured in US dollar \\
10 & SADC & Sum of the value of export by SADC member over the period of study & Measured in US dollar
\end{tabular}

Table 10 Residual Stationarity result

\begin{tabular}{llll}
\hline & ADF test statistic & & PP test statistic \\
\hline Variable & Level & Variable & Level \\
Residual & -5.7089 & Residual & -5.3292 \\
\hline
\end{tabular}

ADF critical values are $-4.2191(1 \%),-3.5331(5 \%),-3.1983(10 \%)$ while critical values for PP are $-4.2268(1 \%),-3.5366(5 \%)$ and $-3.2003(10 \%)$

\section{Abbreviations}

GDP: Gross Domestic Product; COMESA: Common Market for Eastern and Southern Africa; ECCAS: Economic Community of Central African States; ECOWAS: Economic Community of West African States; SACU: Southern African Custom Union; SADC: Southern African Development Community; WTO: World Trade Organization.

\section{Acknowledgements}

Not applicable.

\section{Authors' contributions}

BA wrote the introductory aspect and did the overall vetting of the manuscript. DO, on the other hand, collated the data, analysed the data and wrote the conclusion. All authors read and approved the final manuscript.

\section{Funding}

No funding for the execution of this study.

Availability of data and materials

All the data used are available at the public repository that can be accessible from www.imf.org and https://databank.worldbank.org

\section{Declarations}

\section{Competing interest}

There is no financial and non-financial competing interest as regards this paper.

\section{Author details}

${ }^{1}$ Department of Economics, Obafemi Awolowo University, Ile-Ife, Nigeria.

${ }^{2}$ Monarch Business School, Zug, Switzerland. 
Received: 22 February 2021 Accepted: 26 July 2021

Published: 1 November 2021

\section{References}

1. Adam, S. The works 1811-1812, London, volume 5

2. Admassu S (2017) An empirical analysis of the trade-creation effect of African regional economic communities. Empir Econ 56(3):843-863

3. Afesorgbor SK (2017) Revisiting the effect of regional integration on African trade: evidence from meta-analysis and gravity model. J Int Trade Econ Dev 26(2):133-153

4. Anderson JE, van Wincoop E (2004) Trade costs. J Econ Literat 42:691-751

5. Baldwin RE (1994) Towards an integrated Europe, vol 25, No. 234. Centre for Economic Policy Research, London

6. Bergrstrand JH, Egger P (2009) Gravity equations and economic frictions in the world economy. In: Bernhofen D, Falvey R, Greenaway $D$, Krieckemeier $U$ (eds) Palgrave handbook of international trade. Palgrave-Macmillan Press, New York

7. Bonga-Bonga L, Mabe QM (2019) How financially integrated are trading blocs in Africa? Quart Rev Econ Finance 75:84

8. Dickey DA, Fuller WA (1979) Distribution of the estimators for autoregressive time series with a unit root. J Am Stat Assoc 74:427-431

9. Engle RE, Granger CWJ (1987) Cointegration and error correction: representation, estimation and testing. Econometrica 55:251-276

10. Geyer HS (2019) Global value chain participation and trade barriers in Sub-Saharan Africa. In: Value chains in Sub-Saharan Africa, pp. 13-26. Springer, Cham.

11. Inanch S, Mahamat AH (2019) Trade creation and trade diversion effects in the economic community of central African states. Afr Dev Rev 31(3):307-317. https://doi.org/10.1111/1467-8268.12391

12. International Monetary Fund. (2020). 700 19th street, N.W. Washington, DC. 20431. www.imf.org.

13. Jambo HL (2021) An empirical investigation into the benefits of regional integration from COMESA for Zambia. Int J Econ Policy 1(1):14-41
14. McKay A, Thorbecke E (2015) Economic growth and poverty reduction in sub-Saharan Africa: current and emerging issues. Oxford University Press, Oxford

15. Musila JW (2005) The intensity of trade creation and diversion in COMESA, ECCAS and ECOWAS acomparative analysis. J Afri Econ 14(1):117-141

16. Ogbor JO, Eromafuru EG (2018) Regional trade blocs, location advantage and enterprise competitiveness in the global economy. Archiv Business Res 6(6): 11

17. Olakojo SA (2015). Export commodity prices and long run growth of primary commodities-based African economies. Centre for the study of the Economies of Africa, Abuja Nigeria. CSEA Working Paper WPS/15/02.

18. Olayungbo DO, Yinusa DO, Akinlo AE (2011) Effects of exchange rate volatility on trade in some selected sub-Saharan African countries. Mod Econ 2(4):270-274

19. Phillips $P C B$, Perron $P(1988)$ Testing for a unit in time series regression. Biometrica 75:335-346. https://doi.org/10.1093/biomet/7.52.335

20. Ravenstein EG (1889) The laws of migration. J R Stat Soc 52(2): 241305

21. Rojid S (2006) COMESA trade potential: a gravity approach. Appl Econ Lett 13(14):947-951

22. Ricardo D (1817) On the principles of political economy and taxation. London John Murray, Albemarle-Street.

23. Sarker R, Jayasinghe $S$ (2007) Regional trade agreements and trade in agri-food products: evidence for the European Union from gravity modeling using disaggregated data. Agric Econ 37(1):93-104

24. Shinyekwa IM, Othieno L (2016) Uganda's intra-east african community customs union trade performance in comparison to other trading blocs: a gravity model analysis. J Afr Dev 18(1):99-111

25. Tinbergen J (1962) Shaping the world economy: suggestions for an international economic policy. The Twentieth Century Fund, New York

26. World Development Indicator (WDI) (2020) The World Bank $1818 \mathrm{H}$ street N.W. Washington, D.C. 20433, USA.

\section{Publisher's Note}

Springer Nature remains neutral with regard to jurisdictional claims in published maps and institutional affiliations.

\section{Submit your manuscript to a SpringerOpen ${ }^{\circ}$ journal and benefit from:}

- Convenient online submission

- Rigorous peer review

- Open access: articles freely available online

- High visibility within the field

- Retaining the copyright to your article

Submit your next manuscript at springeropen.com 